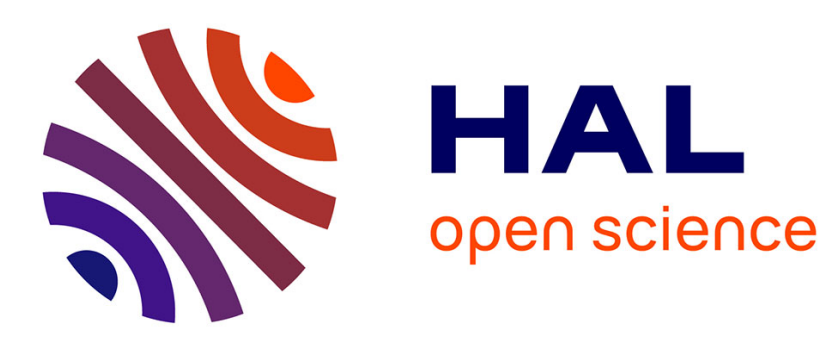

\title{
Effect of water-activity on mold growth and mycotoxin production
}

Daniel Richard-Molard, Laurence Lesage-Meessen, B. Cahagnier

\section{To cite this version:}

Daniel Richard-Molard, Laurence Lesage-Meessen, B. Cahagnier. Effect of water-activity on mold growth and mycotoxin production. Properties of water in foods, Martinus Nijhoff Publishers, 1985. hal-02855352

\section{HAL Id: hal-02855352 \\ https://hal.inrae.fr/hal-02855352}

Submitted on 8 Jun 2020

HAL is a multi-disciplinary open access archive for the deposit and dissemination of scientific research documents, whether they are published or not. The documents may come from teaching and research institutions in France or abroad, or from public or private research centers.
L'archive ouverte pluridisciplinaire HAL, est destinée au dépôt et à la diffusion de documents scientifiques de niveau recherche, publiés ou non, émanant des établissements d'enseignement et de recherche français ou étrangers, des laboratoires publics ou privés. 


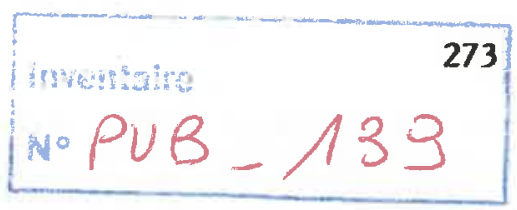

$\therefore$

EFFECT OF WATER ACTIVITY ON MOLD GROWTH AND MYCOTOXIN PRODUCTION

\author{
D. Richard-Molard, L. Lesage and B. Cahagniex
}

\title{
1. INTRODUCTION
}

Molds which contaminate agricultural products, foods and feeds, form a very heterogenous group of microorganisms in respect of their water requirements. Most microfungi occurring in such products need very high $a_{w}$, close to the maximum, to develop, but some genera include species able to grow at much lower $a_{w}$ levels. Jarvis (32) makes the distinction between hygrophilic fungi, unable to develop below $0,90 a_{W}$, mesoxerophilic species which can grow at $a_{W} 0,90-$ 0,80 and xerophilic fungi capable of growth below $a_{W} 0,80$. Pitt (65) defines xerophiles as "fungi which are capable of growth, under at least one set of environmental conditions, at $a_{W}$ below $0,85^{\prime \prime}$. This limit seems to be of some practical interest but it is probably better today to consider such species as "xerotolerant" (11, 14, 21) and to reserve the term "xerophilic" for the very few molds which are markedly inhibited by high $a_{W}$ levels like Monascus bisporus.

Among about 5000 genera of fungi now recognized, only eleven contain xerotolerant and xerophilic species; almost all of these species are Ascomycetes or probable asexual forms of them (65). Adaptation to reduced $a_{w}$, which allows the growth of extreme xero-" philes down to $0,62-0,65 \mathrm{a}_{\mathrm{W}}$, represents therefore a mechanism restricted to a very few highly specialized species.

Compared to many hygrophilic microfungi, xerotolerant molds, which belong main1y to genera Aspergillus, Eurotium and Penicillium, are also characterised by a very high ability to sporulate. Thus they have a great ability to disseminate which probably explains the high frequency of contamination in the agricultural and food industries and more particularly in products with medium or low moisture content,

D. Simatos and J.L. Multon (editors), Properties of Water in Foods. ISBN 90-247-3153-4.

(C) 1985, Martinus Nijhoff Publishers, Dordrecht. Printed in the Netherlands. 
in the range of $0,90-0,60 a_{\mathrm{w}}$. On the other hand, true xerophiles are often reluctant to sporulate so that some very important xerophilic species are not universally found.

Long believed to be harmless, molds, or at least some of them, are now known to produce molecules highly toxic for man and animals. Intensive research over thirty years in the field of mycotoxins has shown that about 150 - 200 species of microfungi are potentially toxigenic $(32,52)$. Mycotoxigenic fungi include some hygrophilic strains like Fusarium species but most of them are capable of growth below $0,90 a_{w}$ and this connexion between xerotolerant and mycotoxi- : genic fungi gives the true dimension of the problem of mold growth in foodstuffs. Fortunately, few of the "real" xerophiles are toxigenic and there are few reports of mycotoxin production below $0,85 \mathrm{a}_{\mathrm{w}}$.

Although a variety of molds may grow on the surface of foods of animal origin such as dry sausages or some dairy products $(9,39$, $61)$, the best substrates for mold growth and mycotoxin production have been shown to be stored seeds, their products and further processed foods. Examples given in the present paper will be taken in this field.

\section{INFLUENCE OF AW LEVELS ON MOLD DISTRIBUTION IN FOOD MATERIALS}

Xerotolerant molds occur everywhere. The primary inoculum for most of them is found on decaying plant material and agricultural products of plant origin are always but generally scantily contamined in the field. After the harvest, grains, seeds and other low $a_{W}$ ecological niches are frequently recontamined by a secondary inoculum of xerotolerant and xerophilic molds present in elevators, mills or factories (64). In many processes, primary contaminants are inactivated by heating and mold growth on bakery goods or dried fruits is due to recontamination by this secondary inoculum.

Due to this constant contamination, food spoilage by molds depends mainly on environmental factors, the water activity being doubtless the most important to be considered $(65,74,79)$. Foodstuffs with water activities above $0,90-0,93$ are generally more subject to rapid bacterial spoilage than to fungal spoilage (Fig. 1): This is not because fungi cannot grow at so high $a_{w}$, but because in such conditions bacteria are highly competitive, growing faster than yeasts and molds $(10,80)$. Spoilage by bacteria, including pathogenic, species, represents the major factor limiting the storage life of so called "highly perishable products", such as fish and meat. Nevertheless, moulding is often a problem in this $a_{w}$ range with fresh fruits or recontaminated bakery goods. Below 0,90 to $0,85 \mathrm{a}_{\mathrm{w}}$, only some bacteria (cocci, lactic bacteria) can still grow and spoilage 


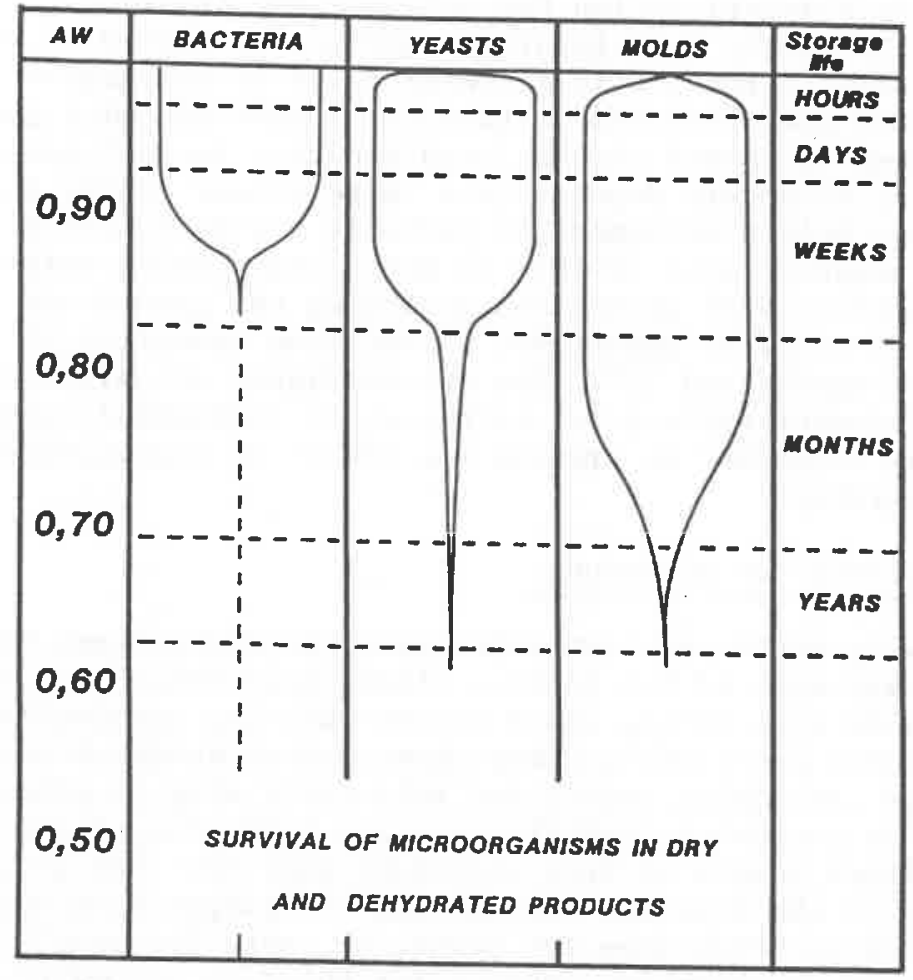

Figure 1. Diagram of microbiological spoilage of boodstufos in relation to water activity.

by yeasts and molds becomes predominant although occuring more slowly.

Below $0,85 a_{w}$, all non-halophilic bacteria are inhibited and in particular Staphylococcus aureus (42), which is certainly the most xerotolerant pathogenic bacterium contaminating foods. In this $a_{W}$ range, xerophilic (or osmophilic) yeasts are still able to grow or to slowly develop fermentative activities in products with high sugar or salt contents such as jams, dried fruits, honey, dry sausages and hams. As a general rule, yeasts prefer liquid or semi-liquid media probably due to their relative "immobility" and tolerance to anaerobiosis (85). On the other hand, and owing to their mycelial growth, molds appear to be microorganisms best adapted to solid substrates with low moisture contents such as grains and their products.

\section{WATER ACTIVITY, MOLD GROWTH AND MYCOTOXIN PRODUCTION}

Biochemical, technological and nutritional consequences of microfungi in grains and related products are well known today. They include such damages as decrease in germinative capacity, dry matter 
losses, 1ipid deterioration and self-heating in silos $(20,73)$. At present, one of the most important questions related to mold growth in foodstuffs is the possible biosynthesis of mycotoxins and most of the research now conducted in this field concerns this question. Nevertheless it should not be forgotten that in most cases the attitude of consumers depends to a large extent on the visual aspect and obvious mold development is probably the main factor in refusing finished products even if they do not contain toxic metabolites. So the understanding of mechanisms governing the growth and sporulation of molds is of first importance in the food industry. In addition, it must be emphasized (55) that the available detoxification methods. are still unsatisfactory for technical or economical reasons, so that it remains necessary to prevent the growth of xerotolerant molds in food materials.

3.1. Life cycle of microfungi

Basically different from unicellular microorganisms such as bacteria and most of the yeasts, filamentous fungi have a more or less complex life cycle, which begins with the germination of a dormant spore producing a first hypha called promycelium. Except under very particular conditions this first step is generally followed by extension, ramification and formation of cross-walls in hyphae. After a more or less important pure mycelial growth, depending on the external conditions, the fungus develops more differentiated structures for sexual or, more frequently, asexual reproduction as shown in Figure 2 for Eurotium chevalieri.

This species can reproduce either asexually (Aspergillus form with conidiophores producing phialospores) or sexually with ascopores formation. Each of these main developmental phases is characterized by different water requirements ; germination occurs at lower $a_{w}$ than

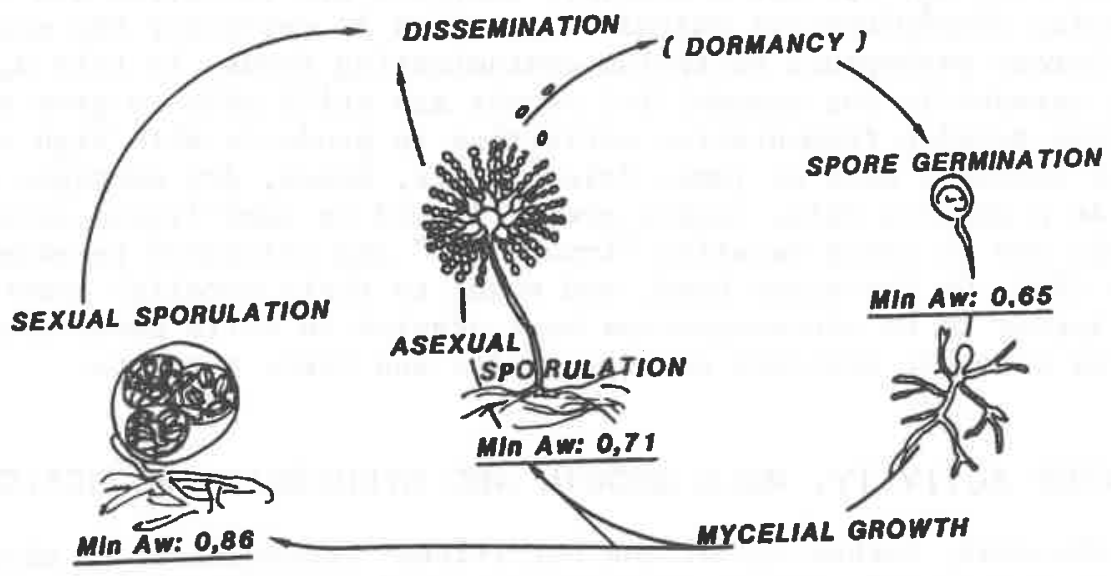

Figure 2. Life cycle of Eurotium chevalieri and $a_{w}$ requirements. 
asexual sporulation and sexual reproduction requires higher $a_{\mathrm{W}}$ levels $(57,66,83)$. For practical purposes, limiting $a_{w}$ levels for sporulation are the most relevant, since they allow fungi to complete their life cycle, which is the condition for extensive growth and marked degradation of substrates (65).

\subsection{Limiting $a_{w}$ levels allowing mold growth}

As shown in Figure 3 (86), in liquid culture medium, the mycelial growth of molds follows the classical growth curve of microorganisms. It begins with a lag phase followed by a phase of rapid growth which can be compared to the exponential growth of unicellular microorganisms. After the maximum stationary phase, a phase of decline can be observed due to progressive autolysis of aged mycelium. Schematically, as recalled by Troller (87), reducing $a_{w}$ levels of the substrate increases the lag period, decreases the rate of growth and reduces the maximum level of development (Fig. 4). At the limit, all other conditions being optimal, the lag phase can be considered as unlimited and the minimum $a_{w}$ value permitting the growth of a given species is
so established.

Since the introduction of the water activity concept in food microbiology $(54,78,79)$, the $a_{w}$ limiting levels for numerous molds, especially xerotolerant and xerophilic species, have been published. Recently reviewed by Pitt (65) and Beuchat (11), some of them are listed in Table I in which are included values published by Snow (83), Pelhate (65), Pitt and Christian (66), Ayerst (3), Mislivec and Tuite

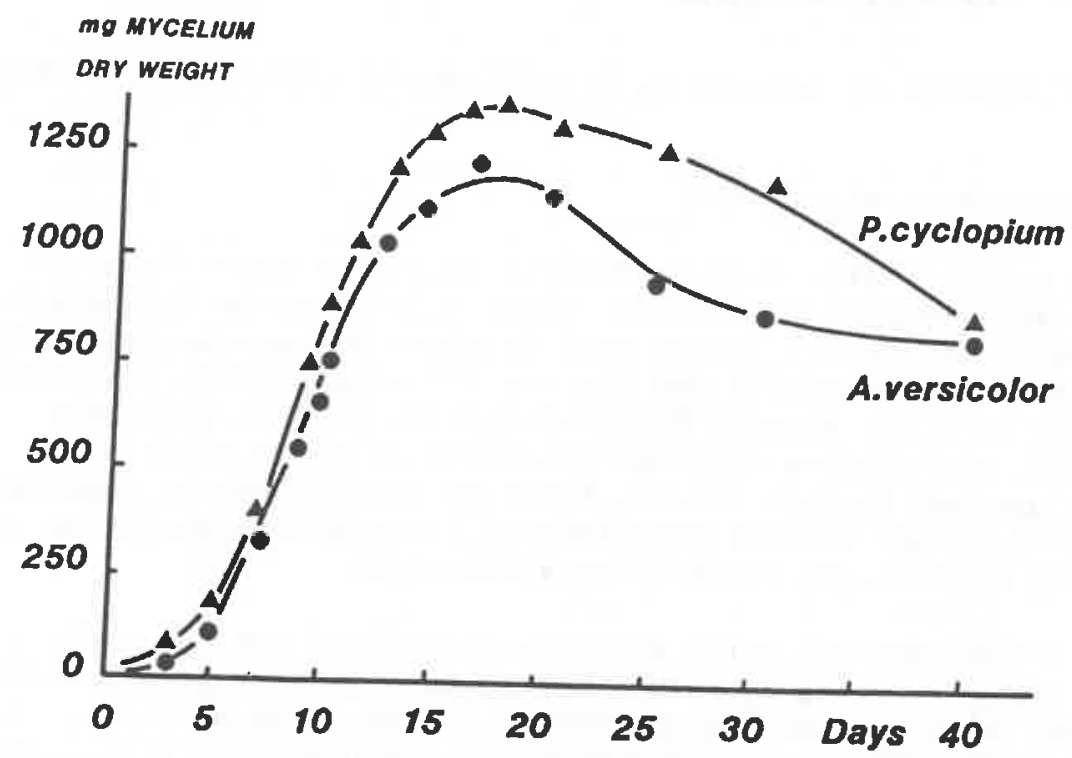

Figure 3. Growth curves of Penicillium cyclopium and Aspergillus versicolor (stationary cultures on liquid medium). 


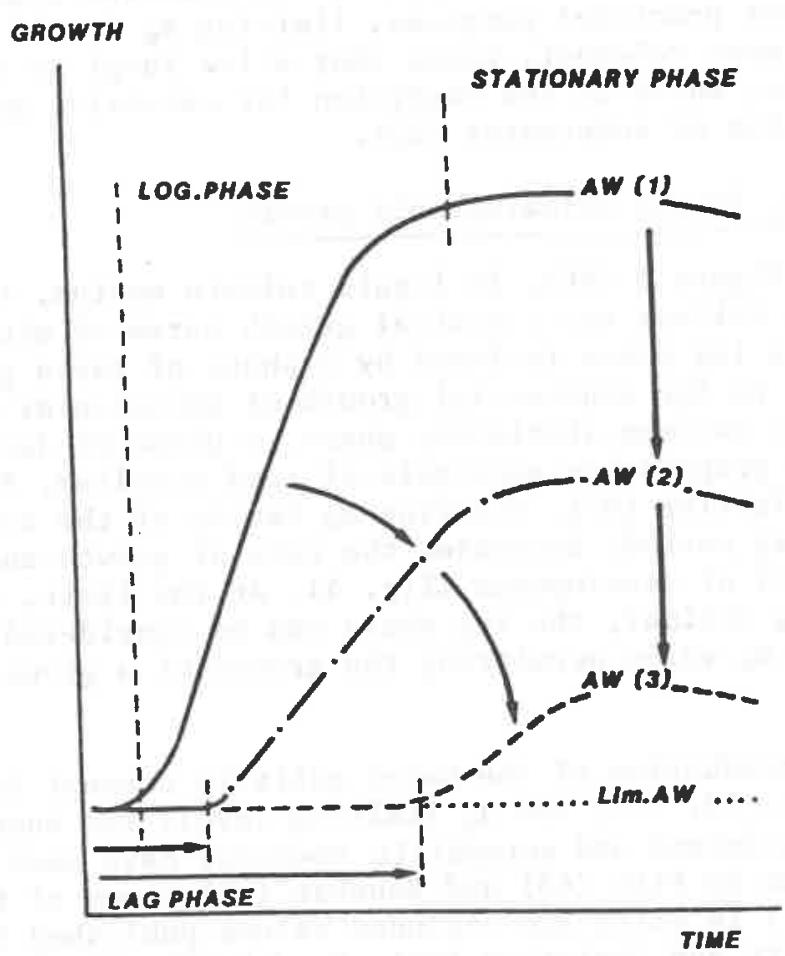

$A W(1)>A W(2)>A W(3)$

Figure 4. Effects of reduced $a_{w}$ on mold growth-Adapted from (87).

(50), Northolt et a1. (56-58).

Quite surprisingly, data previously published about Fusarium species are very scarce, although these species occur very frequently on at least some cereal grains such as wheat and maize. According to Schneider (77) and Armolik and Dickson (2) some species can develop at $a_{w}$ near to 0,90 . Because Fusarium species produce different mycotoxins, new studies on water relations of these molds are urgently needed. To some extent, Fusarium species can be considered as parasitic fungi so that experimental inoculations on grains in laboratory experiments could be questionnable.

From a more general point of view, as pointed out by Seiler (80), most of these limiting $a_{w}$ values were obtained under experimental conditions with optimal culture media. It now seems necessary to complete them with observations made in more practical situations taking into account for instance the biochemical composition of the substrate or the interaction which can occur between strains. This 
Table 1. Approximate minimum aw for growth of some molds at temperature near optimal.

\begin{tabular}{lcc}
\hline \multicolumn{1}{c}{ Fungal species } & $a_{\mathrm{w}}$ & Reference \\
\hline Stachybatris atra & 0,94 & $(31)$ \\
Botrytis cinerea & 0,92 & $(83)$ \\
Trichothecium roseum & 0,90 & $(63)$ \\
Penicillium funiculusum & 0,90 & $(50)$ \\
Fusarium sp & 0,90 & $(2)$ \\
Cladosporium herbarum & 0,88 & $(83)$ \\
Aspergillus wentii & 0,84 & $(66)$ \\
Penicillium cyclopium & 0,85 & $(3)$ \\
Penicillium islandicum & 0,83 & $(29)$ \\
Penicillium expansum & 0,82 & $(56)$ \\
Aspergillus flavus & 0,80 & $(3)$ \\
Aspergillus niger & 0,77 & $(66)$ \\
Aspergillus ochraceus & 0,77 & $(63)$ \\
Wallemia sebi & 0,75 & $(3)$ \\
Eurotium chevalieri & 0,71 & $(2)$ \\
Eurotium amstelodami & 0,70 & $(66)$ \\
Chrysosporium bastidium & 0,69 & $(63)$ \\
Euratium echinulatum & 0,65 & $(66)$ \\
Monascus (Xeromyces) bisporus & 0,61 & \\
& & \\
\hline
\end{tabular}

point of view leads to experiments in which the growth of fungi is more carefully related to the expected shelf-life of feeds and foods stored under real conditions of time, temperature or packaging (19, $55,62,76)$. So in the coming years, one can expect the setting up of "practical" $a_{w}$ levels for stability with respect to mold growth, at least for some important groups of foods or raw materials, taking into account the actual storage times in industrial conditions.

\subsection{Water activity and mycotoxin production}

Mycotoxins are nonantigenic substances, toxic for man and animals, which can be elaborated by molds in various foods and feeds but especially in cereal grains, other seeds and their products. Some of these toxic fungal metabolites, such as aflatoxin $B_{1}$, are carcinogenic, the others producing various disease syndromes, so that every effort must be made to prevent food contamination by mycotoxins. Mycotoxigenic fungi are principally found in three genera : Fusarium, Aspergillus and Penicillium (30, 52, 65). Fusarium species are known to be hygrophilic but most of the other are more or less xerotolerant.

Some of the limiting $a_{w}$ values for mycotoxin production are 1 isted in Table II, in which data recently reviewed by Leistner et al. (41) and Northolt and Bullerman (55) are complemented mainly by those of Northolt et al. (56-58), Lotzsch and Trapper (43, 44), Le Bars (37, 
Table II. Limiting $a_{w}$ levels for mycotoxin production (minimum reported values).

\begin{tabular}{|c|c|c|c|}
\hline Mycotoxins & Fungal species & $a_{w}$ & Reference \\
\hline Af1atoxin & $\begin{array}{l}\text { Aspergillus flavus } \\
\text { Aspergillus parasiticus }\end{array}$ & $\begin{array}{l}0,80 \\
0,83 \\
0,82 \\
0,87\end{array}$ & $\begin{array}{l}(13) \\
(56) \\
(43) \\
(56)\end{array}$ \\
\hline Penicillic acid & $\begin{array}{l}\text { Aspergillus ochraceus } \\
\text { Penicillium cyclopium }\end{array}$ & $\begin{array}{l}0,80 \\
0,88 \\
0,97\end{array}$ & $\begin{array}{l}(5) \\
(57) \\
(57)\end{array}$ \\
\hline Ochratoxin A & $\begin{array}{l}\text { Aspergillus ochraceus } \\
\text { Penicillium cyclopium } \\
\text { Penicillium viridicatum }\end{array}$ & $\begin{array}{l}0,85 \\
0,83 \\
0,87 \\
0,83\end{array}$ & $\begin{array}{l}(5) \\
(57) \\
(57) \\
(43)\end{array}$ \\
\hline Patulin & Penicillium sp & 0,88 & (11) \\
\hline Cyclopiazonic acid & Penicillium sp & 0,87 & (11) \\
\hline Roquefortine & Penicillium sp & 0,87 & (11) \\
\hline Citrinin & Penicillium sp & 0,90 & (11) \\
\hline PR Toxin & Penicillium sp & 0,90 & (11) \\
\hline Penitrem A & Penicillium sp & 0,94 & (11) \\
\hline Zearalenone & Fusarium sp & - & - \\
\hline Trichothecenes & Fusarium sp & - & - \\
\hline Moniliformin & Fusarium sp & - & - \\
\hline Sterigmatocystin & Aspergillus sp & - & - \\
\hline Is 1anditoxin & Penicillium sp & - & - \\
\hline Luteoskyrin & Penicillium sp & - & - \\
\hline Rubratoxin & - & - & - \\
\hline
\end{tabular}

38) for others mycotoxins such as ochratoxin A, patulin, penicillic and cyclopiazonic acids. Data on the $a_{w}$ levels required for mycotoxin formation are still scarce, as shown in Table II, and important differences are often evident among published values for one given species producing a given mycotoxin. This is probably due to the nature and composition of the growth substrate which seems to have a great influence on metabolic pathways leading to mycotoxin accumulation.

At present, most available data deal with aflatoxins, produced by Aspergillus flavus and $A$. parasiticus on various agricultural products and large differences exist in the limiting $a_{W}$ values so far published 
for aflatoxins. The lowest $a_{w}$ levels permitting aflatoxin $B_{1}$ biosynthesis are near to 0,80 (13) but limiting values of 0,83 $0,85 a_{w}$ are frequently reported. Penicillic acid is also produced at very low $a_{w}$ levels $(0,80)$ as shown by Bacon et al. (5) in a study with poultry feeds inoculated with Aspergillus ochraceus. With both Penicillium viridicatum and A. ochraceus, ochratoxin A begins to accumulate in laboratory media at $0,83 a_{\mathrm{W}}$ (57).

As a general rule, it is considered that the limits of toxin production are higher than those for growth, but this introduces the very important question of the influence of mold growth itself on the $a_{w}$ of the substrate : it is indeed well known that due to respiration, heat and metabolic water are produced during growth so that the activity of water is locally and progressively increased $(20,53,72)$. This is why the concept of limiting $a_{w}$ levels for mycotoxin production must be used with caution, especially for products such as grains and seeds which can be stored for long periods.

It seems that for processed foods and feeds such an evolution presents only a limited risk because, according to Jarvis (32), contamination by mycotoxins never occurs before an extensive growth of molds so that alterations become visible or at least perceivable by sensory evaluation. Nevertheless, the situation can be quite different with raw materials for which subsequent drying or other treatments could mask fungal deterioration without destroying the toxins. One of the most acute problems in this regard is probably sneak contaminations of animal feeds with aflatoxin $B_{1}$, leading to aflatoxin $M_{1}$ in milk. As indicated by Leistner et al. (41), limiting $a_{W}$ levels for toxin production are also dependant on the levels at which toxins can be detected. Thus, new developments in methods for toxin detection could make it necessary to verify some old data and to determine more accurately the minimal conditions of time and temperature for biosynthesis in products themselves, even for the well known aflatoxins.

The very low toxicity of xerotolerant species in the Eurotium glaucus group is well established (12), but information on the conditions required for toxin production by Fusarium spp is still very scarce. Results obtained by Sherwood and Peberdy (82) suggest limiting $a_{W}$ close to 0,90 for zearalenone production : significant concentrations $(\geqslant 100 \mathrm{ppm})$ have been obtained after 10 months on cereal grains with $23 \%$ moisture content $\left(0,92-0,93 a_{w}\right)$ but because of the experimental conditions employed, these results remain difficult to interpret. With barley, data from Enari et al. (25) confirm the possibility of toxin formation during storage (wet grains stored in cribs for instance) near or even below $0,90 a_{w}$, but only if contamination of the grain by Fusarium sp occurs before harvest. As far as we know, nothing has been yet published for crichothecenes or
moniliformin. 


\section{ADAPTATION TO REDUCED AW}

Studies on the evolution of conidial water content, in Penicillium roqueforti for instance (7), demonstrate an active dehydration of mold spores by syneresis during their formation and maturation. The production of conidia with water contents lower than those of the initial mycelium seems to be a general phenomenon in molds and could be considered a first step in adaptation to reduced $a_{W}$. A concomitant process is the accumulation of polyalcohols in the cytoplasm (6), but until recently these solutes were considered merely energy storage substances. After their dissemination, fungal spores remain dormant due to specific water soluble inhibitors, as shown by Krishnan et a1. (34), in Aspergillus niger. As soon as sufficient water becomes available, the repressive effect of the inhibitor disappears by dilution and germination can occur. Such mechanisms are not yet well known but they could explain the great differences that are observed in water requirements for fungal spore germination.

On the other hand, it is clear that the growth of microorganisms at reduced $a_{W}$ is possible only if the cells are able to accumulate solutes to balance the osmotic pressure on the membrane. In bacteria, ions and amino-acids play this role of "compatible solutes" $(27,49)$. In yeasts, the compatible solutes seem to be polyalcohols, mainly glycerol and arabitol (15-17) but other results suggest more complex mechanisms for osmoregulation $(1,51)$. In fungi, recent work confirms the role of glycerol as an osmoregulatory substance $(28,46,47)$ and shows that mechanisms involving potassium ion accumulation also occur.

The intracellular accumulation of osmoregulatory substances can be achieved either by absorption or by synthesis (24). If because of the substrate composition, the cell is obliged to synthesize such solutes, it utilises energy. As a general rule, one can perhaps consider that the lower is the outlay of energy for osmoregulation, the higher is the tolerance to reduced water activities.

\section{INTERACTIONS BETWEEN AW AND OTHER PARAMETERS}

Basically, with systems at equilibrium, thermodynamic water activity of substrates is doubtless the most influential parameter. Nevertheless, other parameters and especially temperature, chemical composition and physical structure of substrates, or gazeous environment, may have a considerable influence on mold growth.

\subsection{Particular effects of temperature}

Beside the generally well known effect of temperature which produces an increase in water requirements as soon as the system is shifted from the optimal temperature for mold growth, more particular effects can be observed. In recent experiments (Fig. 5) we have shown 


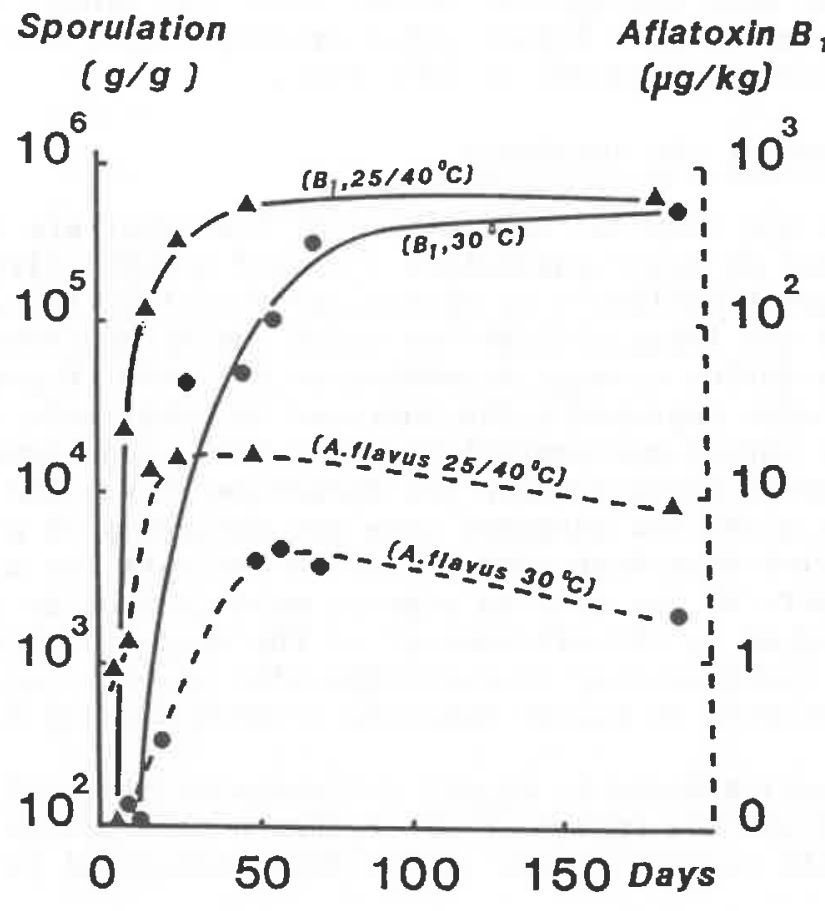

Figure 5. Sporulation and mycotoxin production by Aspergillus flavus on rice $\left(a_{\omega}: 0,93\right)(-)$ Aflatoxin production at $(\bullet) 30^{\circ} \mathrm{C} .(--)$ Sporulation under ( $)$ cycling temperature $25-40^{\circ} \mathrm{C}$.

an activation of growth and metabolic activity by cycling temperatures. Compared to a constant equivalent temperature of $30^{\circ} \mathrm{C}$, cycling temperatures varying between $25^{\circ} \mathrm{C}$ and $40^{\circ} \mathrm{C}$, i.e. about 10 hours at $25^{\circ} \mathrm{C}$ followed by 10 hours at $40^{\circ} \mathrm{C}$, lead to an increased sporulation rate for Aspergillus flavus on rice and a faster aflatoxin synthesis (84).

In these experiments simulating the thermal variations which can be undergone by grain during storage, relative humidity is "controlled" by a salt solution $\left(\mathrm{KH}_{2} \mathrm{PO}_{4}\right)$ giving $92 \% \mathrm{RH}$ at $30^{\circ} \mathrm{C}$ and oscillating between $91 \% \mathrm{RH}$ at $40^{\circ} \mathrm{C}$ and $93 \% \mathrm{RH}$ at $25^{\circ} \mathrm{C}$ (89). So probably only slight variations of $a_{w}$ are introduced in the system by such cycling temperatures and the mechanism of activation is not yet clear. It could be due to an increase in the availability of water at the surface of the grain where molds are located, but another possibility is a particular response of fungi to such conditions which could be studied by calorimetry. This effect has been confirmed with mainze at various relative humidities (Richard-Molard and Cahagnier, 1983, unpublished results) and similar results have 
been obtained with Aspergillus parasiticus, the biosynthesis of aflatoxin $\mathrm{B}_{1}$ being even higher under cycling temperature $\left(5 / 25^{\circ} \mathrm{C}\right)$ that a constant temperature of $25^{\circ} \mathrm{C}(60)$.

\subsection{Influence of the substrate}

Structure and chemical composition of the substrate are generally not considered as major parameters for mold growth, although they may have a great influence on mycotoxin production (55). In Figure 6 , are shown the large differences which can be observed in mycoflora growth rates during storage depending on the kind of grains and seeds (70). Each curve represents the increase in total mold count with time. From a purely mycological point of view, such comparisons cannot be considered as valid because the mycoflora is not the same in each case but for practical purposes they are obviously of great interest. Similar studies have been carried out to estimate the ability of the different parts of the seed to support mold growth. As a general rule, the higher is the oil content of the seed, the more rapid the growth. The accessibility of nutrients also plays a very important role, as indicated by faster moulding of mechanically damaged grains.

Recent results shown in Figure 7 (Lesage et al., 1983, unpublished) demonstrate the influence of lipids on mold growth at reduced $a_{W}$. The growth of Penicillium implicatum, inoculated from a pure

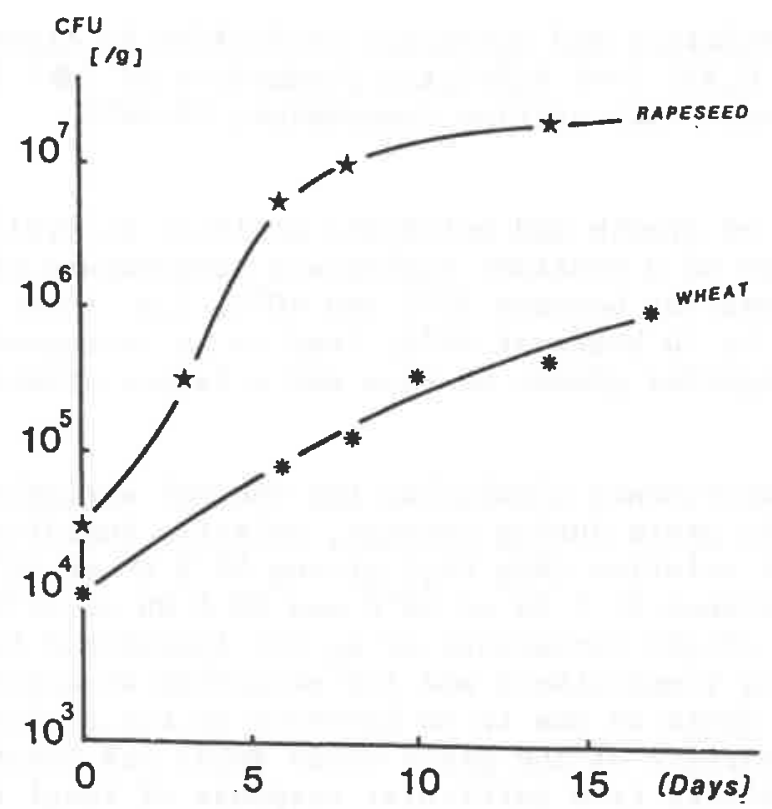

Figure 6. Influence of the substrate on the growth speed of total mycoflora (E.R.H. $85 \%$. Temperature $22^{\circ} \mathrm{C}$ ) Adapted from (70). 


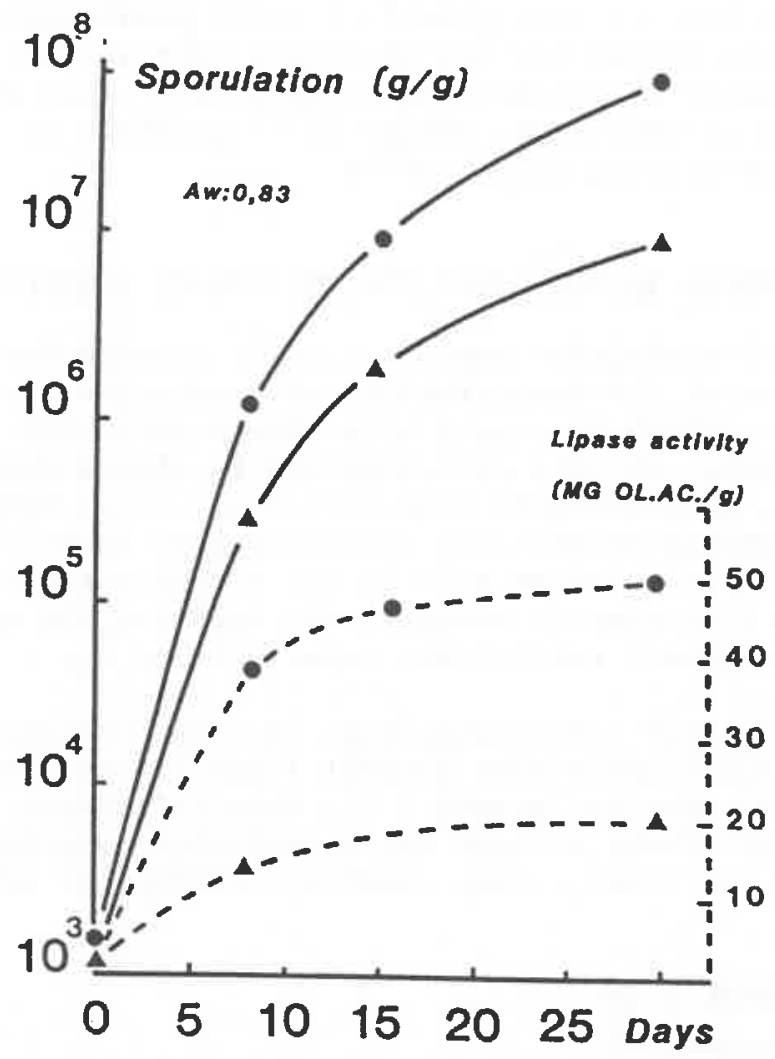

Figure 7. Influence of neutral lipids on $(-)$ sporulation and $(--)$ lipase activity of Penicillium implicatum on (0) whole and (A) defatted meal of maize llipase activity is expressed as fatty acids produced from triolein by one gramm of moldy meal.

culture, is faster on whole coarse meal of maïze than on defatted meal, neutral lipids being previously removed by soxhlet extraction. This effect was observed at $0,83 \mathrm{a}_{W}$, well above the 1 imiting $a_{W}$ level for the growth of Penicillium implicatum $\left(0,78 \mathrm{a}_{\mathrm{W}}\right)(29)$, and could be much more important nearer to this limit, suggesting some connexion between the lipolytic ability of molds and their xerotolerance.

Lipids are also implicated in aflatoxin biosynthesis and correlations have been demonstrated between the lipolytic activity and the capacity to produce mycotoxins in Aspergillus flavus toxigenic strains (4, 26, 36). For Aspergillus parasiticus, toxinogenes is is stimulated by saturated fatty acid (myristic, palmitic and stearic acids) whereas unsaturated fatty acids seem to have inhibitory effects ( 71$)$. 
These few examples show the influence that the temperature or the substrate may have on mold growth or toxin production and as a consequence the impracticality of taking into account only the activity of water to predict the shelf-life of food products, in the present state of knowledge, unless it is possible to reduce $a_{W}$ below the minimum permitting mold growth.

\section{MOLD GROWTH DETERMINATION ON SOLID SUBSTRATES}

Mold growth estimation remains a major problem for solid foodstuffs because of the impossibility of separating the mycelium from the substrate, which is simple with liquid substrates of synthetic laboratory media. So this determination is always made by indirect measurements, more often by enumeration of colony forming units, such units representing essentially asexual spores in xerotolerant fungi. Unfortunately, sporulation rate is not a constant criterion and varies greatly from a species to another, and even for one species depends on the environmental conditions, especially on $a_{w}$.

Under particular conditions, e.g. if oxygen becomes the limiting factor, the sporulation rate in most fungi is considerably reduced as compared to mycelial growth (75). Mycelial growth and toxinogenesis of Aspergillus flavus without any sporulation have been observed on cheeses (61) and other recent studies confirm that aflatoxin formation

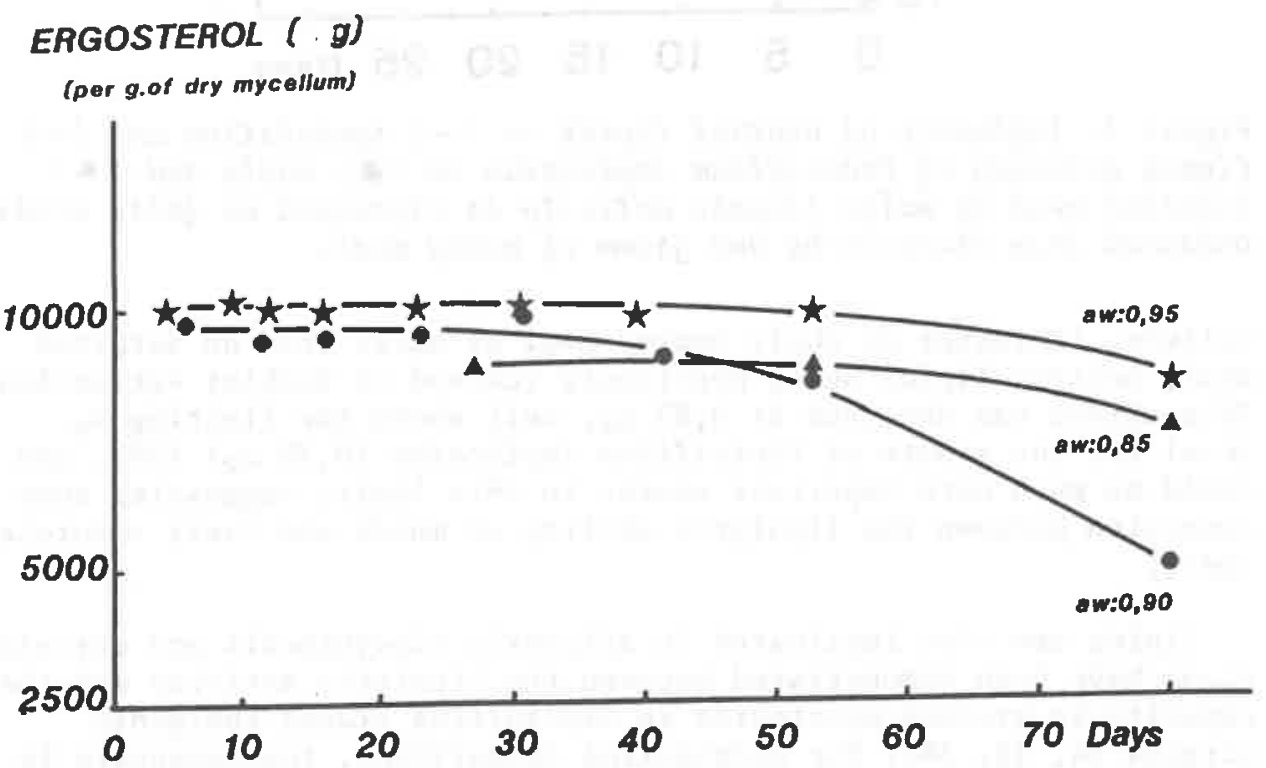

Figure 8. Ergosterol content of Aspergillus candidus mycelium grown at various $a_{w}$ levels. 
is not necessary correlated with sporulation (8). This obviously represents an important problem for both public health and methodology.

Different techniques have been proposed or effectively used to overcome this problem. Landers et al. (36) measured the accumulation of fatty acids in peanuts invaded by Aspergillus flavus. But this criterion depends both on the substrate and the species and cannot be generalised. The determination of chitin, a cell wall component for most of fungi has been used with success on various foodstuffs : $(22,23)$. For grains and seeds frequently invaded by insects and mites, such determinations can lead to major errors.

Another possibility is the measurement of ergosterol content (81). This mycosterol found in fungal membranes is quite specific of fungal growth in the grains so far studied (18). Recent results (Fig. 8) obtained in liquid synthetic media with Aspergillus candidus show that the ergosterol content of mycelium grown at various $a_{w}$ can be considered constant at least during the "exponential" growth. Taking experimental error into account, it can be claimed that the ergosterol content of mycelium varies only slightly with $a_{W}$ in the range $0,80-$ 0,95 (Richard-Molard and Cahagnier, 1983, unpublished).

In contrast, Figure 9 demonstrates the absence of a linear relationship between sporulation and total mold growth estimated by ergosterol determination. If $a_{w}$ is reduced from 0,93 to 0,85 , sporulation curves show only a slight retardation, whereas ergosterol content demonstrates that actual fungal growth is reduced at least three-fold. These preliminary results indicate that such a method gives a more objective estimation of mold growth in solid media. This could be of use in the study of growth and toxin formation by Fusarium species which do not sporulate readily.

\section{CONCLUSIONS}

Some aspects related to water requirements of microorganisms in foods have been neglected in this short review devoted to fungi, when they seemed to be of little practical interest. The kind of solutes added for instance in intermediate moisture foods to reduce $a_{w}$, which is of great importance for bacteria, seems to affect fungal growth

- only very slightly (67). Likewise, molds are relatively indifferent to the $\mathrm{pH}$ of foods or raw materials in the range usually encountered.

- The effect of $a_{w}$ on viability and survival of fungal spores is not basically different from that on bacterial spores and the heat resistance of fungi, as of bacteria, increases at reduced $a_{w}(23$, 48). Molds are also more susceptible to water soluble antifungal agents such as propionic acid or to gamma-irradiation at high $a_{w}$ levels $(68,69)$. Obviously the complete destruction of fungi in foods 


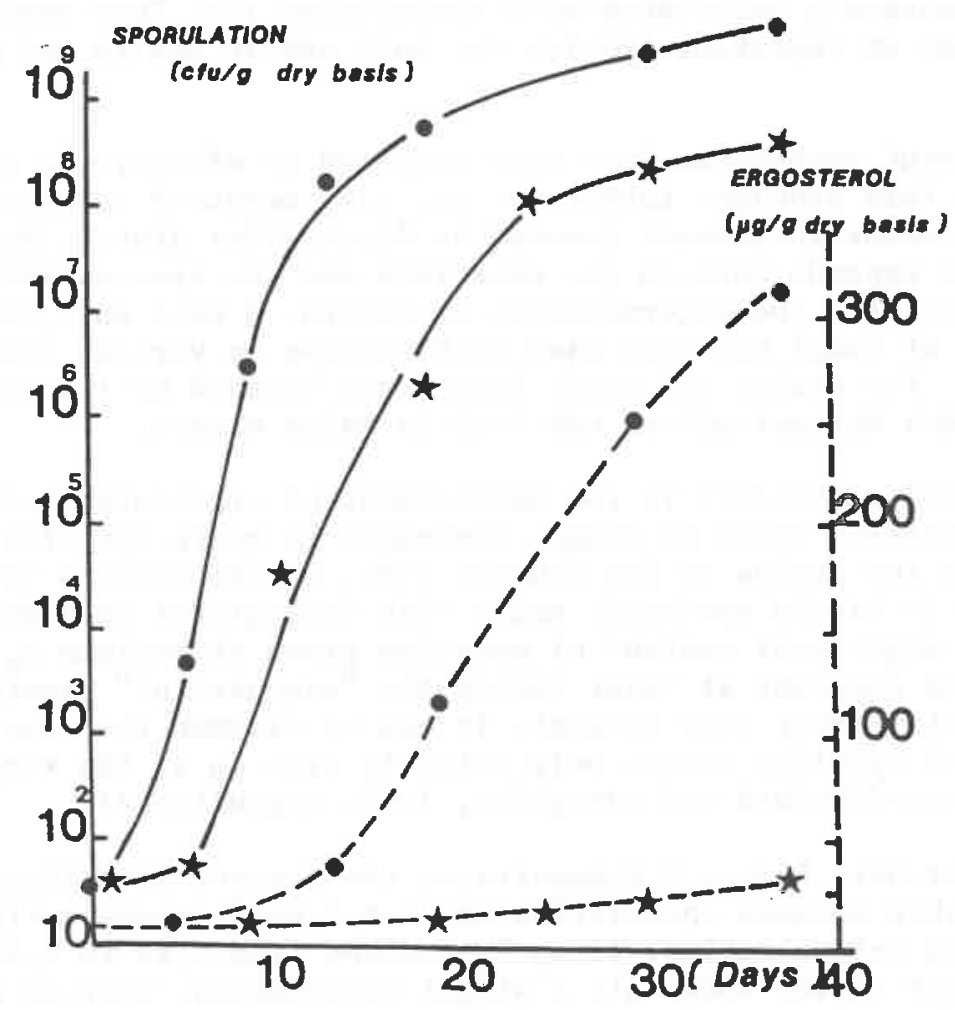

Figure 9. Comparison of sporulation and mycelial growth lestimated by ergosterol content) of Aspergillus candidus on maize at $(0) 0,90$ $a_{w}$ and $(t) 0,82 a_{w}$.

is an impossible objective in the present rate of food technology. In most cases, the treatments which should be necessary remain incompatible with technological and organoleptical qualities, even when economically possible. Even for baked products with sterile surfaces such as bread, problems of moulding exist due to recontamination after baking. Thus, the primary aim in food preservation against xerotolerant molds is to prevent or to adequately retard their growth and metabolic activity. As said before, because of consumer preferences, the preventing growth and sporulation appears to be as important for food technologist as the prevention of mycotoxin formation.

If sufficient time is available, xerotolerant fungi are certainly the most capable microorganisms to overcome the various "hurdles" (40) which can be usually utilised : reducing $a_{W}$, cooling and freezing, airtight packaging or addition of antifungal agents like propionates or sorbates if processes or legislation allow such addi- 
tions. For economic, technological or organoleptical reasons, it is often impossible to set up these hurdles at levels that control xerotolerant molds, and further quantitative research is needed, in practical situations, on the effects of several hurdles in combination on the moulding of naturally contaminated foods.

From the toxicological point of view, very little is yet known about possible synergisms between several mycotoxins simultaneously produced on the same commodity. For example, severe nephrotoxicosis due to a probable synergy between ochratoxin $A$ and citrinin has been " reported by Krogh et al. (35), whereas Vesela et al. (88) claimed a simple additive effect of these two mycotoxins. With cereal grains invaded by Fusarium species, several toxic substances are often produced together and basic information on the resulting toxicity is urgently needed.

On a more fundamental level, much remains to be done to fully explain the mechanisms of adaptation to reduced $a_{W}$ in microfungi. In particular, it would be very interesting to understand how xerotolerant and xerophilic molds perceive variations of water activity, as such knowledge could lead to new methods for preventing fungal growth. 


\section{REFERENCES}

1. Adler L. and Gustafsson L. (1980). Archives of Microbiology, $124,123$.

2. Armolik N. and Dickson J.G. (1956). Phytopathology, 46, 462.

3. Ayerst G. (1969). J. Stored Prod. Res., 5, 127.

4. Ba D., Jemmali M. and Drapron R. (1977). Ann. Microbiologie, $128 \mathrm{~B}, 87$.

5. Bacon C.W., Sweeney J.G., Robins J.D. and Burdick D. (1973). App1. Microbio1., 26, 155.

6. Bailo A., Di Vittorio V. and Russi S. (1964). Arch. of Biochem. and Biophysics, 107, 177.

7. Barer R. and Joseph S. (1958). J. App1. Bacteriol., 21, 146.

8. Batt C. (1983). J. Food, Saft., 5, 1, 31.

9. Benard G. and Labie CH. (1977). Rev. Med. Vet., 128, 7, 975.

10. Beuchat L. (1981). Cereal Foods World, 26, 7, 345.

11. Beuchat L. (1983). J. of Food Protec., 4b, 2, 135.

12. Blaser P., Ramstein M., Schmidt-Lorenz W. and Schlatter CH. (1980). Lebensm. Wiss. u. Technol., 14, 66.

13. Boller R.A. and Schroeder H.W. (1974). Phytopathology, 64, 17.

14. Brown A.D. (1976). Bact. Rev., 40, 803.

15. Brown A.D. (1977). Advances in Microbial Physiol., 17, 181.

16. Brown A.D. (1978). J. of Bacteriology, 118, 3, 769.

17. Brown A.D. and Simpson J.R. (1972). J. of General Microbiol., 72, 589.

18. Cahagnier B., Richard-Mo1ard D. and Poisson J. (1983). Sc. des Alim., 3, 219.

19. Chang H.G. and Markasis P. (1981). Cereal Chem., 58, 2, 89.

20. Christensen C.M. and Kaufman H.H. (1974). In : "Storage of Cereal Grains and their Products" (C. Christensen ed.) AACC Inc. St Paul, Minnesota.

21. Corry J.E.L. (1978). In : "Food and Beverage Mycology" (L. Beuchat ed.) AVI Pub. Co. Westport, CT.

22. Donald W.W. and Mirocha C.J. (1977). Cereal Chem., 54, 466.

23. Doyle M.P. and Marth E.H. (1975). J. of Milk and Food Technol., 38,678 .

24. Edgley M. and Brown A.D. (1977). J. of General Microbiol., 104, 343.

25. Enari T.M., Ilus T. and Niku-Paavola M.L. (1981). Appl. Microbiol. and Biotechn., 11,241 .

26. Fane11i C. and Fabri A.A. (1981). Trans. Br. Myco1. Soc., 77, 2, 416.

27. Gould G.W. and Measure J.C. (1977). Phil. Trans. Royal Soc. London, B, 278, 151 .

28. Griffin D.M. (1981). Advances in Microb. Ecology, 5, 91.

29. Hocking A.D. and Pitt J.I. (1979). Trans. Br. Mycol. Soc., 73, 141 .

30. Hawker L.E. and Madelin M.F. (1976). In : "The Fungal Spore" (D.J. Weber and W.M. Hess eds) John Wiley, Pub1. New-York.

31. Jarvis B. (1971). J. App1. Bact., 34, 1, 199. 
32. Jarvis B. (1976). In : "Intermediate Moisture Foods" (R. Davies, G.G. Birch and K.J. Parker eds) Appl. Sc. Pub. London.

33. Jarvis B. (1977). J. of Food Technol., 12, 581.

34. Krishnan P.S., Bajaj V. and Damle P.P. (1954). Appl. Microbio1., $2,303$.

35. Krogh P. (1974). Acta Path. Microbio1. Scand,, A, 246.

36. Landers K.E., Davis N.D. and Diener U.L. (1967). Phytopathology, $57,10,1086$.

37. Le Bars J. (1979). App1. Environ. Microbiol., 38, 6, 1052.

38. Le Bars J. (1980). Ann. Rech. Vet., 11, 3, 321.

39. Leistner L. and Ayres J.C. (1968). Fleischwirtschaft, 48, 62.

40. Leistner L. and Rödel W. (1976). In : "Intermediate Moisture Foods" (R. Davies, G.G. Birch, K.J. Parker eds) App1. Sc. Pub1. London.

41. Leistner L., Rödel W. and Krispkien K. (1981). In : "Water activity : Influence on Food Quality" (L.B. Rockland and G.E. Stewart, eds) Acad. Press. London.

42. Lotter L.P. and Leistner L. (1978). App1. Environ. Microbio1., 36, 377.

43. Lötzsch R. and Trapper D. (1978). Fleischwirtschaft., 58, 12 , 2001 .

44. Lötzsch R. and Trapper D. (1979).. Proceed. of 4th IUPAC Symposium on mycotoxins, Lausanne.

45. Luard E.J. (1982). J. of General Microbio1., 128, 2563.

46. Luard E.J. (1982). J. of General Microbiol., 128, 2575.

47. Luard E.J. and Griffin D.M. (1981). Trans. Br. Mycol. Soc., 76, 33.

48. Lubienieki Von Schelhorn M. and Heiss R. (1975). In : "Water Relations of Food" (R.B. Duckworth ed.) Academ. Press. London.

49. Measure J.C. (1975). Nature, London, 257, 398.

50. Mislivec P.B. and Tuite J. (1970). Mycologia, 62, 75.

51. Moran J.W. and Witter L.D. (1979). J. of Bacteriology, 138, 823.

52. Moreau C. (1974). Moisissures toxiques dans l'alimentation (Masson ed.) Paris.

53. Mosse1 D.A.A. (1975). In : "Water Relations of Foods" (R.B. Duckworth ed.) Academic Press, London.

54. Mosse1 D.A.A. and Westerdijk J. (1949). Antonie van Leeuvenhoek, $15,190$.

55. Northolt M.D. and Bullerman L.B. (1982). J. of Food Protect., $45,6,519$.

56. Northolt M.D., Van Egmond H.P. and Paulsch W.E. (1978). J. of - Food Protect., 41, 11, 885 .

-57. Northo1t M.D., Van Egmond H.P. and Paulsch W.E. (1979). J. of Food Protect., 42, 6, 476.

58. Northolt M.D., Van Egmond H.P. and Paulsch W.E. (1979). J. of Food Protect. 42, 6, 485.

59. Panasenko V.T. (1967). Bot. Rev., 33, 189.

60. Park K.Y. and Bullerman L.B. (1981). J. Food Sc., 46, 4, 1147.

61. Park K.Y. and Bullerman L.B. (1983). J. of Food Protect., 46, 3, 178. 
62. Pelaez J. and Karel M. (1980). J. of Food Process. Preserv., 4, $1-2,51$.

63. Pelhate J. (1968). Mycopatho1. Mycol. App1., 36, 117.

64. Pelhate J. (1982). In : "Conservation et Stockage des Grains et Graines" (J.L. Multon ed.) APRIA-Lavoisier, Paris.

65. Pitt J. (1975). In : "Water Relations of Foods" (R.B. Duckworth ed) Academic Press, London.

66. Pitt J. and Christian J.H.B. (1968). Appl. Microbiol., 16, 1853.

67. Pitt J. and Hocking A.D. (1977). J, of Gene. Microbiol., 101, 35.

68. Poisson J., Cahagnier B. and Guilbot A. (1971). Mycopathol. Myco1. App1., 45, 3-4, 193.

69. Poisson J. and Cahagnier B. (1973). Ann. Technol. Agric., 22, 4, 567.

70. Poisson J. and Cahagnier B. (1979). Techn. Ind. Cereal., 169, 3-7.

71. Priyadashini E. and Tulpule P.G. (1980). Food Cosm. Toxicol., $18,4,367$.

72. Reiss J. (1978). Z. Lebensmitt. Untersuch. u. Forsch., 167, 6, 419.

73. Richard-Molard D. (1982). In : "Conservation et Stockage des Grains et Graines" (J.L. Multon ed.) APRIA-Lavoisier, Paris.

74. Richard-Molard D., Bizot H. and Multon J.L. (1982). Sc. Alim., Spec. Issue II, 3.

75. Richard-Molard D., Cahagnier B., Poisson J., Bertrand D. and Lebras A. (1983). Colloques INRA (in press).

76. Sauer D.B. and Burroughs R. (1980). Phytopathology, 70, 6, 516.

77. Schneider R. (1954). Phytopathol.Z., $21,63$.

78. Scott W.J. (1953). Anst. J. Biol. Sc., 6, 549.

79. Scott W.J. (1957). Adv. in Food Res., 7, 83.

80. Seiler D.A.L. (1976). In : "Intermediate Moisture Foods" (R. Davies, G.G. Birch, K.J. Parker eds) Appl. Sc. Pub. London.

81. Seitz L.M., Mohr H.E., Burroughs R. and Sauer D.B. (1977). Cereal Chem., 11, 171 .

82. Sherwood R.F. and Peberdy J.F. (1972). J. Stored Prod. Res., 8, 71 .

83. Snow D. (1949). Ann. App1. Bio1., 36, 1.

84. Syarief R. (1983). Thesis University of Nantes, Nantes.

85. Tilbury R.H. (1976). In : "Intermediate Moisture Foods" (R. Davies, G.G. Birch and K.J. Parker eds) App1. Sc. Pub. London.

86. Trique B. (1969). Thesis University of Brest, Brest.

87. Troller J.A. (1980). Food Technol., 34, 5, 76.

88. Vesela D., Vesely D. and Jelinek R. (1983). App1. Environ. Microbiol., 45, 1, 91 .

89. Young J.F.' (1967). J. App1. Chem., 17, 241. 